\title{
Lacrimal Sac Pseudotumour - A Case Report
}

\author{
Anushree Gupta* \\ Dr. Radhakrishnan Government Medical College, India
}

Submission: September 04, 2018; Published: September 21, 2018

*Corresponding author: Anushree Gupta, M.B.B.S, D.N.B (Ophthalmology), Dr. Radhakrishnan Government Medical College, Hamirpur, Himachal Pradesh, India, Tel: 7807498219; Email: anushree0612@gmail.com

\begin{abstract}
Lacrimal sac tumors are rare with a clinical presentation that typically mimics chronic dacryocystitis. A full history with clinical and diagnostic workup is essential to plan treatment. Herein we report the case of a 50-year-old woman with inflammatory pseudotumour of the lacrimal sac confirmed by histopathological section.
\end{abstract}

Keywords: Lacrimal sac tumours; Epiphora; Dacryocystitis

Abbrevations: CT: Computed Tomography; MPL: Medial Palpebral Ligament

\section{Introduction}

A patient presenting with chronic epiphora and mass in the medial canthal region can be due to many causes, most commonly being chronic dacryocystitis. It is usually associated with inflammatory signs, purulent discharge and a soft, fluctuant mass typically below the medial canthal tendon. Persistent epiphora with an irreducible mass above the medial canthal tendon should arouse the suspicion of a tumour. Early diagnosis and ancillary investigations are important to rule out malignancy as they are locally invasive and life threatening.

\section{Case Report}

A 50 year-old indian woman presented to our eye department at Dr. Radhakrishnan Government Medical College, Himachal Pradesh, India in June 2018 with a 6 month history of epiphora and swelling at the medial canthal area of the left eye. There was no history of fever or any mucopurulent discharge from the eye. There was no history of trauma or infection previously. Patient had already taken course of topical and systemic antibiotics at a local hospital with no relief of symptoms.

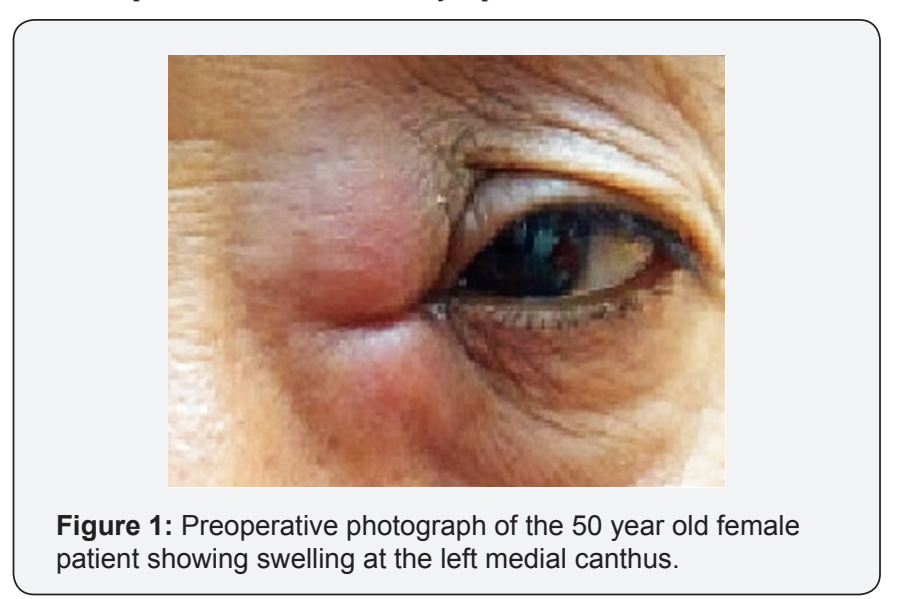

Her best corrected visual acuity was 20/20 in both the eyes. There was a protrusion superior to medial canthus and a firm, nontender mass was palpable at the medial side of the left orbit (Figure 1). It was $3 \mathrm{~cm} \times 2 \mathrm{~cm}$ in dimensions extending above and below the medial canthal tendon. There was mild erythema overlying the swelling. There was no displacement of globe. On lacrimal syringing test of left eye, reflux of fluid was seen through the opposite punctum. Syringing test of right eye was patent. Pressure over the mass did not cause regurgitation of contents through either punctum. Anterior segment and fundus examination were normal. Endoscopic endonasal examination demonstrated normal nasal cavity and no bulge in the lateral wall.

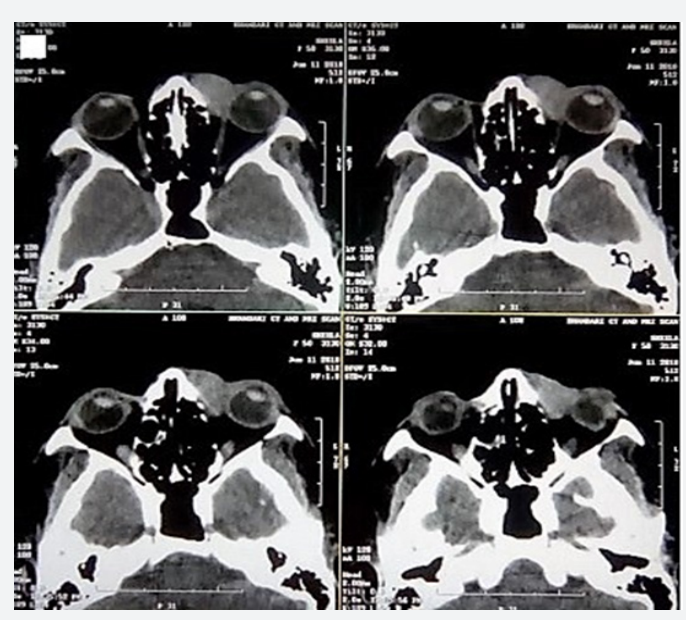

Figure 2: Preoperative Computed Tomography scan of the orbit showing a well defined $3 \mathrm{~cm}$ mass in the left lacrimal sac region 
A computed tomography imaging identified a well defined lobulated hyperechoic mass lesion in the left lacrimal sac fossa region measuring $30 \times 18 \mathrm{~mm}$. No involvement of extraocular muscles, bony erosion or globe infiltration was seen (Figure 2).

General physical and systemic examination was normal. Routine blood and urine investigations were normal. Chest X ray and Ultrasound abdomen were normal. The patient underwent excisional biopsy of the mass, lacrimal sac and proximal portion of the nasolacrimal duct.

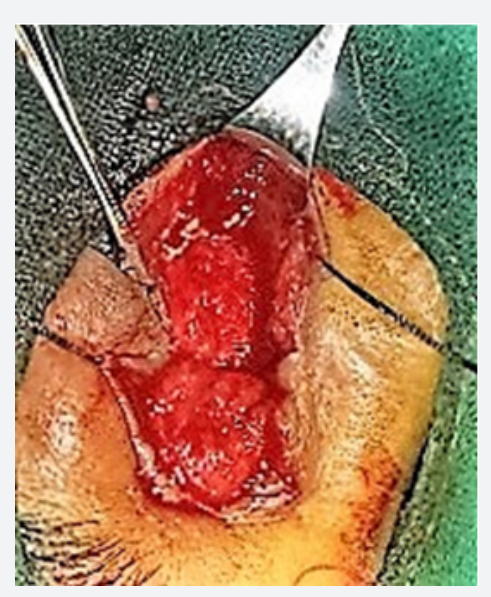

Figure 3: Intraoperative photograph of the patient showing the well defined mass after blunt dissection.

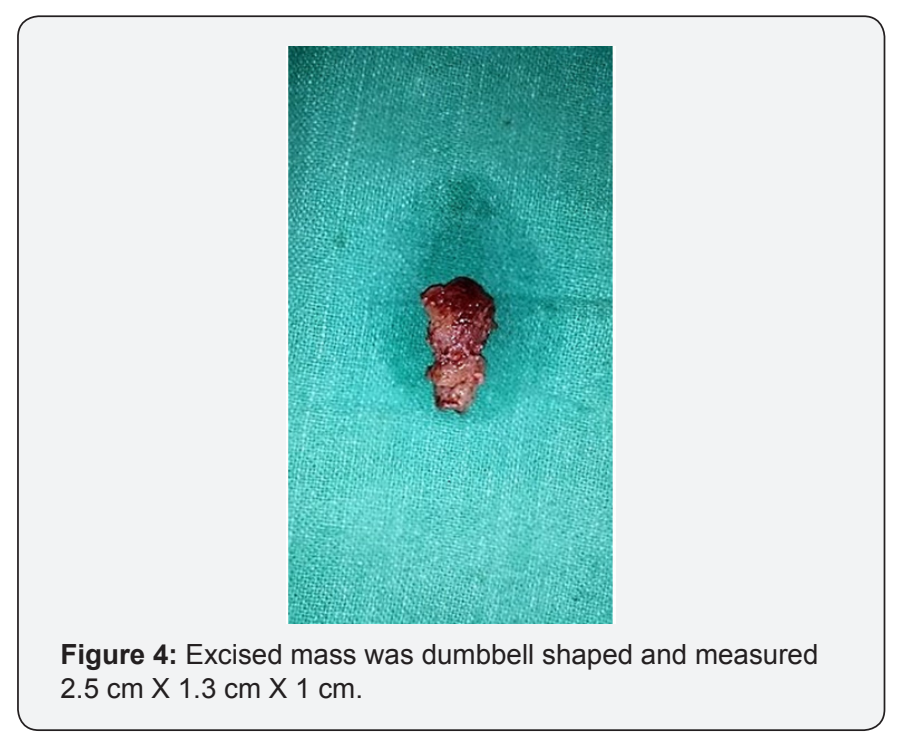

The surgery was performed under local anaesthesia with sedation. Skin incision was made $3 \mathrm{~mm}$ from the medial canthus and was extended $1 \mathrm{~cm}$ above and $2 \mathrm{~cm}$ below the medial canthus. Blunt dissection was done, MPL was identified and divided. A solid, well circumscribed dumbbell shaped mass was seen without any infiltration to the surrounding structures (Figure 3). It was then separated from the surrounding structures by blunt dissection followed by cutting its connections with the canaliculi (Figure 4). Wound were closed with interrupted sutures. Pathologic examination demonstrated a solid grey -brown mass composed of mixed inflammatory cells such as lymphocytes and plasma cells. One month post surgery the patient underwent repeat CT scan and no mass was seen.

\section{Discussion}

Lacrimal sac tumors typically present with epiphora and a palpable mass over the medial canthus and are thus often misdiagnosed as chronic dacryocystitis [1]. A full history with clinical and diagnostic workup is essential to plan treatment. Tumours of the lacrimal sac can be divided into pseudotumours and true tumours. Pseudotumours include mucocoele, granulomatous disorder, nonspecific inflammatory disorder, amyloidosis etc [2]. Lacrimal sac malignancies are quite rare and are further divided into primary and secondary tumours. Primary tumours can be epithelial, lymphoproliferative, mesenchymal or melanotic in origin. Most tumors are primary and of epithelial origin (60-94\%), of which about 55\% are malignant. The most common primary neoplasm of lacrimal sac are epithelial tumours, squamous cell papilloma and squamous cell carcinoma $[3,4]$.

It is important to rule out malignancy in any patient presenting with persistent epiphora with a mass above medial canthal tendon, globe displacement and / or history of bloody tears [5]. Work up of a patient with suspected lacrimal sac tumour should include an orbit CT scan and tissue biopsy. Definitive diagnosis is made on the basis of histopathological examination [6].

In this case the diagnosis of pseudotumour was made after exclusion of neoplasm, infection and systemic disorders. The patient was managed with an open Dacryocystectomy and a favourable postoperative outcome was seen.

\section{Acknowledgement}

I would like to express my deepest appreciation to Dr. Shruti Anand, Assistant Professor, Ophthalmology, Dr Radhakrishnan Government Medical College, Hamirpur who provided me the guidance and encouragement to complete this report.

\section{Declaration of patient consent}

The authors declare that they have obtained all appropriate patient consent forms. In the form the patients have give their consent for their images and other clinical information to be reported in the journal. The patients understand that their names and initials will not be published and due efforts will be made to conceal their identity, but anonymity cannot be guaranteed.

\section{Financial support and sponsorship}

Nil.

\section{Conflicts of Interest}

The authors declare no conflicts of interest.

\section{References}

1. Lee JS, Lee H, Chang M, Park M, Baek S (2015) Benign mixed tumor of the lacrimal sac. Indian J Ophthalmol 63(3): 282-284. 
2. Mohammed Javed Ali (2010) Principles and practice of Lacrimal surgery. ( $2^{\text {nd }}$ edn), Springer, pp.419-421.

3. Krishna Y, Coupland SE (2017). Lacrimal Sac Tumors - A Review. Asia Pac J Ophthalmol (Phila) 6(2): 173-178.

4. Lee KH, Han SH, Yoon JS (2015) Case Reports of Lacrimal Sac Tumors Discovered in Patients with Persistent Epiphora Following Dacryocystorhinostomy. Korean J Ophthalmol 29(1): 66-67.
5. Kang B, Jung H, Shin JM, Park IH, Lee HM (2017) Clinical Characteristics of Lacrimal Sac Tumors: Report of Ten Cases. J Rhinol 24(1): 14-19.

6. Karim MM, Inoue M, Yamamoto M, Kanomata N, Ohbayashi C, et al. (1995) Inflammatory pseudotumor of the lacrimal sac. Kobe J Med Sci 41(1-2): 19-22.

\section{Your next submission with Juniper Publishers will reach you the below assets}

- Quality Editorial service

- Swift Peer Review

- Reprints availability

- E-prints Service

- Manuscript Podcast for convenient understanding

- Global attainment for your research

- Manuscript accessibility in different formats ( Pdf, E-pub, Full Text, Audio)

- Unceasing customer service

Track the below URL for one-step submission https://juniperpublishers.com/online-submission.php 